\title{
Is the UK Supreme Court rogue to un-prorogue Parliament?
}

\author{
Constantina P. Tridimas ${ }^{1} \cdot$ George Tridimas ${ }^{2}$ (I)
}

Published online: 8 April 2020

(c) The Author(s) 2020

\begin{abstract}
On 24 September 2019, in a unanimous judgment the UK Supreme Court ([2019] UKSC 41) ruled that the Prime Minister's action to prorogue (suspend) Parliament for 5 weeks in the run-up to the 31-10-2019 deadline of the UK leaving the European Union, was unlawful and of no effect, as it prevented Parliament from carrying out its constitutional functions without reasonable justification. Although the Court did not pronounce on the merits and demerits of Brexit, its decision delighted "Remainers" but appalled "Leavers". The Court ruling epitomises the potency of constitutional review by an independent judiciary. The paper applies collective choice theory to analyse the ruling of the Supreme Court. This is accomplished by (a) examining the legal basis of the Court ruling; (b) reviewing arguments for judicial review and (c) exploring the effect of the Court as an additional player in the game of collective choice in a spatial decision model.
\end{abstract}

Keywords Prorogation of Parliament - UK Supreme Court - Separation of powers · Constitutional judicial review $\cdot$ Judicial independence $\cdot$ Veto players

JEL classification $\mathrm{D} 72 \cdot \mathrm{D} 74 \cdot \mathrm{D} 78 \cdot \mathrm{K} 40 \cdot \mathrm{K} 41$

"[I]t is...of course true...that Parliament, the executive and the courts have different functions. But the function of independent judges charged to interpret and apply the law is universally recognized as a cardinal feature of the modern democratic state, a cornerstone of the rule of law itself." Lord Bingham, A and others $v$ Secretary of State for the Home Department [2004] UKHL 56

\footnotetext{
George Tridimas

G.Tridimas@ulster.ac.uk

Constantina P. Tridimas

C.Tridimas@my.bpp.com

1 Law School, London Holborn, BPP University, 68-70 Red Lion Street, London WC1R 4NY, UK

2 Department of Accounting, Finance and Economics, University of Ulster, Newtownabbey, Co. Antrim BT37 0QB, UK
} 


\section{Introduction}

On 24 September 2019, in a unanimous judgment of eleven Justices, the UK Supreme Court, in $R$ (on the application of Miller) $v$ The Prime Minister; Cherry and others $v$ Advocate General for Scotland [2019] UKSC 41, ruled that the Prime Minister's action to prorogue (suspend) Parliament for 5 weeks during the period 09-09-2019-14-10-2019, while the UK was scheduled to leave the European Union on 31-10-2019, was unlawful, because in so doing Parliament was prevented from carrying out its constitutional functions without reasonable justification. The ruling constitutes living proof of the power and effects of constitutional review by a judiciary independent of the executive branch. Although the Court did not express a view about the economic, political and social advantages and disadvantages of Brexit, its verdict pleased "Remainers" but attracted the opprobrium of "Leavers" accusing unelected judges for meddling in political matters. It circumscribed the discretion of the Executive to navigate through the Brexit negotiations with the EU. The ruling of the Court to overturn a decision of the executive demonstrates the review power of an independent judiciary and demonstrates the extent of judicial activism, which critics allege as counter-majoritarian and antidemocratic. ${ }^{1}$ In this view, the Court went rogue and un-prorogued.

This paper applies collective choice theory to analyse the ruling of the Supreme Court. It has a threefold objective. First, in the context of the UK Brexit tumult it examines the legal basis of the Court ruling. Second, it reviews relevant arguments for judicial review found in the literature. Third, it explores the effect of the Court as an additional player in the game of collective choice by using a simple spatial decision model. The paper is structured as follows. The remaining of the Introduction explains the meaning of prorogation. Section 2 presents the sequence of events leading to the Court ruling. Section 3 discusses the ruling of the Court. As the literature on constitutional review by the judiciary is enormous cutting across law, economics, politics and sociology, Sect. 4 briefly sketches explanations based on the rational choice model. Section 5 uses the spatial decision model of collective choice theory to explore the strategic interactions between the Executive, the Parliament and the Court and the decision to un-prorogue. Section 6 concludes.

A prorogation of parliament ends the current session of the UK Parliament. While Parliament is prorogued, neither the House of Commons (elected lower House) nor the House of Lords (unelected upper House) can meet, debate, pass legislation, or hold the executive to account, by for instance asking Ministers written or oral questions, or by meeting in committees. The Government remains in office and can exercise its powers to make secondary legislation but cannot procure the passing of Acts of Parliament or obtain approval for further spending. The decision to prorogue is a prerogative power. $^{2}$ Prerogative powers are powers recognised in common law,

\footnotetext{
1 Judicial activism is the propensity of courts to query the decisions of elected officials and range from "nullifying acts of the legislature, to abandoning neutral principles, to deciding cases in a politically "liberal' or 'conservative' fashion" (Hanssen 2000, p. 538).

${ }^{2}$ For UK government prerogative powers see, for example, Bradley et al. (2018).
} 
which are exercised by the Crown, either by the monarch or government ministers, and can be used without Parliamentary approval. The power to order prorogation lies in the monarch, acting on the advice of her government. As such, in practice, for more than a century, "the Government of the day advises the Crown to prorogue and that request is acquiesced to" ([2019] UKSC 41 [3]). ${ }^{3}$ A short time after prorogation, a new session begins with the Queen's Speech, which sets the legislative programme of the Government. Prorogation differs from dissolution of Parliament, which is followed by a general election to elect a new House of Commons and approve a new government. Similarly, prorogation differs from adjournment of the House (or, equivalently, the House going into recess). The latter is decided by each House passing a motion to that effect, rather than the Government. During a recess, the House does not sit but Parliamentary business can otherwise continue as usual (for example, committees may meet).

\section{Chronicle of developments: “Events dear boy, events"}

On 23 June 2016, the UK held an "In-Out" referendum on its European Union membership (pursuant to the European Union Referendum Act 2015); see the "Appendix" for summary of the timeline of the events from the EU referendum to the ruling of the Supreme Court annulling the prorogation of the Parliament and the exit of the UK from the EU. With a $72.2 \%$ turnout of 46.5 million registered voters, 17.4 million voters voted to Leave and 16.1 million voters voted to remain, which translated into a 51.9-48.1\% victory for leaving the European Union. The latter camp was split into two groups, the official "Vote Leave" Campaign headed by Conservative Ministers Michael Gove and Boris Johnson, and the "Leave.EU" Campaign headed by the Euro-sceptic MEP and the then leader of the UK Independence Party Nigel Farage (who later headed the 'Brexit' party). At the time, the "Vote Leave" group was perceived as more sympathetic to the "Soft" exit option than the latter. ${ }^{5}$ Immediately after the referendum, David Cameron resigned as Prime Minister and Theresa May was chosen as leader of the Conservative party and took his place. On 2nd October 2016, May announced her intention to give notice under Article 50 of the Treaty of the European Union before the end of March 2017. Following a challenge brought by Mrs Gina Miller and others, the Supreme Court held that the Prime Minister had no power to take the country out of the EU without the authority of an Act of Parliament ( $R$ (Miller) v Secretary of State for Exiting the European Union [2017] UKSC 5). Parliament responded by passing the European Union (Notification of

\footnotetext{
3 Throughout the text we denote paragraph numbers of the Supreme Court judgment [2019] UKSC 41 by square brackets [.].

4 Attributed to Harold Macmillan, UK Prime Minister, 1957-63, when asked what a prime minister fears most.

5 A 'soft Brexit' meant a negotiated settlement out of the EU, possibly including elements of customs union and likely participation in the Single Market. A 'hard Brexit' meant withdrawing without a negotiated deal relying only on World Trade Organisation (WTO) rules implying the imposition of tariffs on at least some trade in goods between the UK and the EU.
} 
Withdrawal) Act 2017, which received royal assent on 16th March 2017 and authorised the Prime Minister to give the notification for withdrawal, which Prime Minister May did on 29th March 2017.

A general election was held on 8th June 2017. No party obtained overall majority, but Theresa May secured a "confidence and supply" agreement with the Democratic Unionist Party of Northern Ireland and formed a Government. The European Union (Withdrawal) Act 2018 came into force on 26th June 2018 setting 29 March 2019 as "exit day". From that day, the European Communities Act 1972, the Act which had provided for UK's entry into what has now become the European Union, would be repealed, but much of the existing EU law as the law of the UK was to be preserved (with provision for exceptions and modifications). It stipulated that a withdrawal agreement may only be ratified if (a) the Government presents to Parliament a statement that political agreement has been reached, a copy of the negotiated withdrawal agreement and a copy of the framework for the future relationship; (b) the House of Commons has approved the withdrawal agreement and future framework; (c) the House of Lords has taken note of them both; and (d) an Act of Parliament has been passed which contains provision for the implementation of the withdrawal agreement.

Negotiations about a "smooth and orderly exit from the European Union" and a political declaration, setting out a framework for the future relationship, to be negotiated by the end of 2020, were concluded on 25th November 2018. However, the withdrawal agreement was rejected three times by the House of Commons, on 15th January 2019 (by 432-202 votes), on 12th March 2019 (by 391-242 votes), and on 29th March 2019 (by 344-286 votes). Following this, the European Union (Withdrawal) Act 2019 was passed on 8th April 2019 which required the Prime Minister to seek an extension for leaving the EU, which on 10th April 2019 was granted until 31st October 2019.

Having failed to pass the withdrawal agreement, Theresa May resigned as Prime Minister on 24th July, after the Conservative party had chosen Boris Johnson as its leader. Boris Johnson had declared that in his view the European Council will only agree to changes in the withdrawal agreement if there is a genuine risk that the United Kingdom will leave without any such agreement. He appointed Michael Gove Cabinet Office Minister to prepare for a "no deal" exit. Yet it was also clear that a majority of the House of Commons would not support withdrawal without an agreement. On 27-28 August, acting on the advice of the Prime Minister, although conversations are not made public, the Queen proceeded to make an Order in Coun$\mathrm{cil}^{6}$ that would prorogue Parliament for the period 9 September-14 October.

Parliament returned from its summer recess on 3rd September, when the House of Commons passed a motion that MPs should decide for themselves (rather than

\footnotetext{
${ }^{6}$ Orders in Council are Orders that have been approved at a meeting of the Privy Council personally by the Queen. They fall into two broad categories, statutory and Prerogative. Statutory Orders are made under any of the numerous powers contained in Acts of Parliament which give Her Majesty a power to make Orders. Prerogative Orders are made under the inherent power of the Crown to act on matters for which Parliament has not legislated. See https://privycouncil.independent.gov.uk/orders/ and Bradley et al. (2018).
} 
the Government) what business they would transact. On 4th September they passed a bill requiring that on 19th October the Prime Minister seeks an extension of 3 months from the European Council, unless by then Parliament has either approved a withdrawal agreement or approved leaving without one. On 6th September the House of Lords suspended its usual rules, so that the Bill could be passed, and on Monday 9th September it received Royal Assent to become the European Union (Withdrawal) (No 2) Act 2019. The object of that Act is to prevent the United Kingdom leaving the European Union without a withdrawal agreement.

Meanwhile, on 30 July, a petition was launched by a cross-party group of 75 MPs and members of the House of Lords in the Outer House of the Court of Session of Scotland claiming that a prorogation would be unlawful and seeking a declaration to that effect and an interdict to prevent it. On 4th September the petition was refused on the ground that the issue was non-justiciable in a court of law ([2019] CSOH 70). However, on appeal, the Inner House Court of Session, Scotland's supreme civil court, held that the advice given to the Queen was justiciable, that it was motivated by the improper purpose of stymying parliamentary scrutiny of the executive, and that it, and the prorogation which followed, were unlawful and thus null and of no effect (13 September: [2019] CSIH 49). Nevertheless, the Inner House gave its permission for appealing to the UK Supreme Court.

As soon as the prorogation was announced, Gina Miller also launched proceedings in the High Court in England and Wales, seeking a declaration that the Prime Minister's advice to Her Majesty was unlawful. The Divisional Court dismissed the claim on the ground that the issue was non-justiciable (11 September: [2019] EWHC 2381 (QB)) but granted a "leap-frog" certificate so that the case could come directly to the Supreme Court.

The Supreme Court convened a panel of eleven Justices, the maximum number of serving Justices who are permitted to sit, and heard the two appeals from 17 to 19 September. It delivered a unanimous verdict on 24 September ([2019] UKSC 41). It held that, first, the issue of the lawfulness of the advice given by the Prime Minister to the Monarch is justiciable, since there is no doubt that the courts have jurisdiction to decide upon the existence and limits of a prerogative power. Second, the decision to advise Her Majesty to prorogue Parliament was unlawful because it had the effect of frustrating or preventing the ability of Parliament to carry out its constitutional functions without reasonable justification. It then declared that the prorogation of Parliament was likewise unlawful, null and of no effect.

As our focus here is the legal case and the interactions between the executive, the legislature and the judiciary, we limit our narrative of political events at this point, even though there have been important new developments since which are still playing out (see the "Appendix").

\section{The judgment of the Supreme Court}

The judgment of the Supreme Court considered whether the advice given by the Prime Minister to Her Majesty the Queen on 27th or 28th August 2019 that Parliament should be prorogued from a date between 9th and 12th September until 14th 
October was lawful. The Supreme Court explained that the two appeals raise the same four overlapping issues. (1) Whether the lawfulness of the Prime Minister's advice to Her Majesty is justiciable; (2) the standards used to judge the lawfulness; (3) whether upon applying that standard, it was lawful; and (4) if the advice was not lawful, the remedy that the court should grant.

Regarding justiciability, the Court was firmly of the opinion that the question of whether the Prime Minister's advice to the Queen was lawful was justiciable. This is because, it has long been established that the courts can determine the existence of a prerogative power and its extent (Council of Civil Service Unions $v$ Minister for the Civil Service [1985] AC 374). Justiciability only becomes an issue where the question before the court relates to the lawfulness of the exercise of a prerogative power which has been used within its lawful limits. In these circumstances, the court is not permitted to challenge the use of prerogative powers if the question relates to "high policy", for example the decision to go to war $(R v$ Secretary of State for Foreign and Commonwealth Affairs, Ex p Everett [1989] QB 811, 820). Since the court was determining the limit on the prerogative power to prorogue Parliament, the matter was justiciable, because questions as to the limit of a prerogative power are fundamentally questions of law, which, under the principle of the separation of powers, it is the function of the courts to determine [36].

Moving to the second question, the standard by which the lawfulness of the advice to prorogue is to be judged, the Court needed to first establish the limitations of the prerogative power to prorogue. All prerogative powers are limited, and it is for the courts to determine the extent of that limitation. Courts are responsible for determining the legal limits of the powers conferred on each branch of government, and to decide whether any exercise of power has transgressed those limits. Courts have exercised a supervisory jurisdiction over the decisions of the executive for centuries. $^{7}$ The Supreme Court notes that the fact that the Prime Minister is accountable to Parliament does not in itself rule out a role for the courts, since (a) when Parliament is suspended, prorogation prevents the operation of ministerial accountability to Parliament, and (b) the courts have a duty to give effect to the law, irrespective of the minister's political accountability to Parliament.

The court held that since prerogative powers are recognised by the common law, they must be compatible with common law principles. In respect of prerogative powers that relate to the operation of Parliament, their limits are determined by the fundamental principles of UK constitutional law [38]. Being uncodified, the UK's Constitution consists of the common law, statutes, conventions and practice, as well as principles of law, which are enforceable by the courts [39]. The Supreme Court reaffirmed that constitutional principles apply to circumscribe the exercise of

\footnotetext{
7 The Supreme Court offered two historical examples to illustrate. During the reign of James I (160325), in the Case of Proclamations (1611) 12 Co Rep 74, it was held that it was unlawful to alter the law by the use of the Crown's prerogative. "The King hath no prerogative, but that which the law of the land allows him", indicating that the limits of prerogative powers were set by law and were determined by the courts. Second, in Entick v Carrington (1765) 19 State Tr 1029; 2 Wils KB 275, the court declared that the Secretary of State could not order searches of private property without authority conferred by an Act of Parliament or the common law.
} 
governmental powers which have been conferred both by statute and prerogative powers. It found that the two relevant fundamental principles of constitutional law were Parliamentary sovereignty and Parliamentary accountability. It bears noting that there is an established body of jurisprudence on Parliamentary sovereignty (e.g. $R$ (on the application of Jackson) v Attorney General [2005] UKHL 56). However, relying on the principle of Parliamentary accountability presents a comparatively novel ground of constitutional jurisprudence. We leave this important issue for future research.

Under the principle of Parliamentary sovereignty "the laws enacted by the Crown in Parliament are the supreme form of law in our legal system, with which everyone, including the Government, must comply" [41]. Time and again, in a series of cases since the 17th century, the courts have protected Parliamentary sovereignty from threats posed to it by the use of prerogative powers, and in doing so have demonstrated that prerogative powers are limited by the principle of Parliamentary sovereignty. The Court held that if there was no legal limit on the power to prorogue Parliament, then the executive could use it to "prevent Parliament from exercising its legislative authority for as long as it pleased" [42]. Consequently, the principle of Parliamentary sovereignty is incompatible with an unlimited power or prorogation. Practical constraints, such as the executive requiring Parliamentary authority to raise money to fund public services, were found to offer scant reassurance. It was nonetheless emphasised that prorogation was not in and of itself unlawful and incompatible with Parliamentary sovereignty where Parliament was prorogued for a short time such that there was only a minor effect on Parliament's ability to exercise its legislative powers.

The second relevant fundamental principle of constitutional law, Parliamentary accountability, means that "the conduct of government by a Prime Minister and Cabinet collectively responsible and accountable to Parliament lies at the heart of Westminster democracy" (per Lord Bingham, Bobb v Manning [2006] UKPC 22, 13). That is to say, ministers are accountable to Parliament through their duty to answer Parliamentary questions, appearance before Parliamentary committees and Parliamentary scrutiny of their delegated legislation. Hence, the policies of the executive are scrutinised by the legislature, on behalf of the electorate and citizens are protected from the arbitrary exercise of executive power. Prorogation endangers this principle because "the longer that Parliament is prorogued, the greater the risk that responsible government may be replaced by unaccountable government" [48].

In the same way that unlimited prorogation is incompatible with Parliamentary sovereignty, so it is with Parliamentary scrutiny. Therefore, a prerogative power is limited by the constitutional principles with which it would otherwise conflict (as well as by statute and the common law) [49]. This means that "a decision to prorogue Parliament (or to advise the monarch to prorogue Parliament) will be unlawful if the prorogation has the effect of frustrating or preventing, without reasonable justification, the ability of Parliament to carry out its constitutional functions as a legislature and as a body responsible for the supervision of the executive" (emphasis added) [50]. The question of whether the prorogation frustrates Parliament's ability to perform its legislative function is fundamentally a question of fact for the Court to determine; then the Court must decide whether the Prime Minister's explanation for 
advising that Parliament should be prorogued is reasonably justified, while exercising sensitivity as to the responsibilities and experiences of the Prime Minister. In other words, the latter question is to be considered by the Court with caution.

The third question concerns whether the prorogation prevented Parliament from fulfilling its constitutional functions without reasonable justification. It was held that this prorogation prevented Parliament from carrying out its constitutional role for five out of a possible 8 weeks between the end of the summer recess and the UK's exit from the European Union on 31 October. The main political parties hold their annual conferences over a three-week period in late September-early October, when the Parliament goes to recess. While it was acknowledged that such an interruption might not matter in some circumstances, the circumstances in UK politics were exceptional as "[a] fundamental change was due to take place in the Constitution of the United Kingdom on 31st October 2019. Whether or not this is a good thing is not for this or any other court to judge. The people have decided that. But that Parliament, and in particular the House of Commons as the democratically elected representatives of the people, has a right to have a voice in how that change comes about is indisputable [57]." Furthermore, the court held that no reasonable justification had been given by the government for such a long prorogation. Accordingly, the court held that "[i]t is impossible for us to conclude, on the evidence which has been put before us, that there was any reason-let alone a good reason-to advise Her Majesty to prorogue Parliament for 5 weeks, from 9th or 12th September until 14th October. We cannot speculate, in the absence of further evidence, upon what such reasons might have been. It follows that the decision was unlawful" [61].

Finally, the Court examined the remedy to be granted following the decision that the advice given to the Queen to prorogue Parliament was unlawful. The Government argued that the prorogation was a "proceeding in Parliament" which cannot be challenged in court. The Court dismissed this argument; Parliament did not vote for it, the prorogation was imposed. Therefore, since the Prime Minister's advice was unlawful, it was null and of no effect. Consequently, the Order in Council, upon which the prorogation is ordered, was also unlawful and of no effect [69]. It follows that Parliament has not been prorogued. Parliament, and in particular the Speaker, decides what to do next [70].

Notwithstanding its controversial political context, the Supreme Court handed down a remarkably conservative judgment that affirms the supremacy of the UK Parliament established with the settlement of the 1688 Glorious Revolution. It upholds the traditional system of separation of powers and views its own constitutional position as one of determining "the legal limits of the powers conferred on each branch of government, and to decide whether any exercise of power has transgressed those limits. [Crucially,] the courts cannot shirk that responsibility merely on the ground that the question raised is political in tone or context" [39]. The case is an example of a situation where the Court intervenes to ensure that accountability between the branches of government is guaranteed and effective. Throughout the ruling, the Court emphasizes that the Executive is accountable to the Parliament, and there is no good reason to suspend this obligation. The Supreme Court delivered a judgment that reaffirmed Parliamentary Sovereignty as the principle at the heart of the UK Constitution, continued a tradition "of deference to Parliament", and 
demonstrated that it would intervene to ensure Parliament's continued supremacy. It is submitted that such a strict interpretation of the Constitution insulates the Court from criticisms of judicial activism.

\section{Constitutional judicial review by an independent judiciary}

In a liberal democracy, courts are tasked with the examination and subsequent ratification or annulment of laws and policy measures, passed by the legislature and enacted by the executive branch of government, for their compatibility with the constitution or other relevant statutes (like declarations of basic rights) which take precedence, and have been enacted according to the stipulated procedures (Stone Sweet 2002). Courts are therefore an integral part of the separation of powers, so that no single arm of the state monopolises power. Similarly to ruling in disputes between private parties, judicial review of policy is meaningless unless the reviewing judge is independent of the government.

The 'un-prorogue' ruling is a case of judicial resolution of a dispute between different organs of government, the elected Parliament and the Executive posing as the standard bearer of the 2016 Referendum Leave outcome. In this respect, the involvement of the Supreme Court differs from review of government actions for their consistency with individual rights granted by the law, which is often the focus of the literature on judicial review. ${ }^{8}$ To put it another way, it is the loss of the parliamentary majority of the government at Westminster, which has opened a rare opportunity for the Court to adjudicate between the executive and legislative branches. Irrespective of the nature of disputants, judicial review presents a conundrum: an unelected judiciary is granted the power to reject the decisions of the executive which may enjoy a parliamentary and electoral majority. The question then arises why organs of the state with a claim to democratic legitimacy delegate resolution of constitutional disputes, with their inevitable political consequences, to a Court whose members are not accountable to voters and abide by its rulings. In answering this question, we start by examining the constitution of a polity and apply the tenets of public choice theory of methodological individualism, where the relevant unit for the study of the political process is the individual actor, and rational choice, where the individual maximises expected utility under the relevant constraints. ${ }^{9}$

\footnotetext{
8 The UK courts have long been involved in judicial review of administrative actions. But fully fledged judicial review of legislation for its compatibility with individual rights started in earnest after the 1998 passage of the Human Rights Act which empowered courts to review whether Acts of Parliament are consistent with codified rights. For a detailed analysis, see Kavanagh (2009). Ip (2014, p. 223) offers details and using public choice methodology argues that the Human Rights Act was "primarily designed to maximize the partisan and corporate interests of the enacting legislative coalition."

9 Short reviews of the vast literature on independent judicial review can be found in Harnay (2005) and Tridimas (2014). Voigt (2020) offers the first and so far only textbook treatment of the field of constitutional political economy, which uses the rational choice model of economics to study the emergence of constitutions and their effects on the economic variables of interest.
} 


\subsection{Interpretation of the incomplete constitutional contract}

A constitution is a form of social contract that joins the citizens of the state and defines the set of rules governing their community (Mueller 1996). Constitutions describe "property rights" to political power, that is, the powers of the different organs of state, the limits placed on them, the freedoms of the citizens and mechanisms to protect them. The case studied here concerns the division of power between different branches of the government. However, the constitution is par excellence an incomplete contract. A contract is incomplete when there is uncertainty about the rights, duties, and commitments of the contracting parties. Incompleteness originates from often enormous difficulties to perceive and describe all possible circumstances that may affect the contracting parties (what has become known as bounded rationality rather than full) and the inability of the parties to commit to the relevant actions (which makes a party vulnerable to the opportunistic tendencies of another party). Moreover, conditions change over time, as preferences and technology or random shocks disturb the prevailing equilibrium, thereby changing the interests of the parties to the agreement. Rights and obligations may then be vague and disputable. In view of such uncertainty and ambiguity, parties choose to enter what is called a "relational contract." That is, instead of agreeing to a definite and detailed plan of actions and rewards, the parties frame their relationship by agreeing on basic goals and objectives, on general provisions that are broadly applicable, on the criteria to be used in deciding what to do when unforeseen contingencies arise, on who has the power to act and the bounds limiting the range of actions that can be taken, and on dispute resolution mechanisms to be used. To overcome the incompleteness of the constitution, its signatories delegate the task of resolution of disputes, interpretation of rights, and enforcement of commitments to independent constitutional courts, grant them review powers, and agree to abide by their rulings. In a system of strong judicial review, like the US, the constitutional court can annul legislation it adjudges as incompatible with the constitution. On the other hand, in a system of weak judicial review, like the UK, the court can declare legislation incompatible with the constitutional rights, but leaves it to the legislature to remedy the legislation. Incompleteness is arguably more pronounced in the case of the Constitution of the UK which is not codified but consists of a number of treaties, laws, conventions, practices, and conforms to long established legal principles. ${ }^{10}$

\subsection{The judiciary in the principal-agent relationship}

In this context, the rational choice account couches the judiciary in the architecture of the principal-agent relationship (Law 2009). A principal is an actor who lacking information or competence to take an action furthering its interests

\footnotetext{
10 All the documents comprising the UK constitution can be read at the website of the International Constitutional Law http://www.servat.unibe.ch/icl/. Bogdanor (2009) offers a book-length critical review of the current British constitutional order and its evolution following the Human Rights Act and devolution legislation after 1997.
} 
delegates authority to a knowledgeable and specialised agent to take such action. For example, the voters delegate decision making powers to their elected representatives; or the executive acts as an agent of the legislature to implement its chosen policies. In this light, three partially overlapping roles are attributed to the judiciary. First, the judiciary, independent of the other arms of the state, may mitigate information asymmetry problems and provide authoritative answers to questions about the rules of governance contained in the constitution and the law more general. In the terminology used above, the judiciary fills the gaps left by the incomplete constitutional contract. When the judiciary interprets the constitution, it acts as a trustee of the constitution and exercises fiduciary powers (Majone 2001; Stone Sweet 2002). Under trusteeship, the judiciary holds all political property rights.

Second, an independent judiciary may be well placed to resolve the "strong state dilemma" (Weingast 1993) or "sorcerer's apprentice problem" (Mueller 1996), and the associated time inconsistency problems afflicting the holder of power. A state strong enough to protect the security and wealth of citizens against external or internal predators is strong enough to deprive them of their freedoms and properties and even enslave them. The following time inconsistency may then arise: A ruler may announce that he will respect private property rights so that citizens have the incentive to invest and increase output. However, when on a future date output rises, the ruler actually benefits from disrespecting property rights and confiscating the higher output. That is, the ruler has time or dynamic inconsistent preferences. Anticipating the double cross, citizens do not believe the initial promise of the ruler, refrain from investing and output stagnates. An independent judiciary with the authority to protect citizens and strike down abuses of power by government officials offers a possible solution to this problem and enhances the credibility of policy declarations (Hayo and Voigt 2007). An independent judiciary also resolves commitment problems arising when office seeking politicians pander to parochial public opinion sentiments at the expense of the long-run interest of the society, and promote policies which hurt minorities or trample upon rights. Under this circumstance, when the electorate is poorly informed, information about policy is costly to acquire and slow to emerge, granting power to a judiciary, even though it is unaccountable, may increase social welfare, because the judiciary is immune from electoral objectives (Maskin and Tirole 2004).

In the setting just described, the judiciary engages in resolving conflicts between the state and the citizens. When one considers conflict between political groups competing for office, a third role for independent judicial review emerges, that of political insurance (Landes and Posner 1975; Ramseyer 1994; Ginsburg 2002; Stephenson 2004, Hanssen 2004; Tridimas 2010). When in power, different political parties wish to implement the policies conferring the highest benefits to their supporters. In so doing, they may hurt disproportionately the supporters of opposing parties. Political parties who recognise that their hold on power is only temporary and will be in and out of office appreciate that they are better off if they and their opponents are restrained so their policies do not inflict grave losses to the opposite side. Hence, they grant independence to the judiciary, endow it with the power to 
strike down laws incompatible with the rules which frame the game, and abide by its rulings.

Submitting constitutional disputes to the courts introduces an additional player to the game of collective choice. The last half-century or so has witnessed a dramatic increase of submissions to both domestic and international courts to resolve political disputes of a constitutional nature, a trend which is called the "judicialization of politics (for details see among others Ferejohn 2002 and Shapiro and Stone Sweet 2002). More specifically, the constitutional court enters the collective decision game not as a decision taker who can initiate legislation, but as a veto player, whose consent is required to enact legislation. When the veto player takes a stance on a policy issue differing from the policy preferences of the agenda setters, only comparatively small changes of policy from the status quo, if at all, are enacted (Tsebelis 2002; Congleton 2011). In general, settings with several institutional or partisan veto players, who have different policy ideals, will display greater policy stability. This may frustrate politicians attempting to introduce new policies, leading to accusations of policy paralysis. Politicians who see the judiciary as blocking them from applying their promises may then accuse courts of interference in politics and partisan bias. ${ }^{11}$

\subsection{Judicial independence}

A necessary (although not sufficient) condition for judicial review is judicial independence. To resolve disputes in an unbiased way judges with the power to issue binding rulings must be protected against threats and intimidation, and stay independent of the disputants. Specifically, judicial independence means that courts enforce the law and resolve disputes without regard to the power and preferences of the parties appearing before them (La Porta et al. 2004). Judicial independence is an imperative element of the rule of law and its beneficial consequences. ${ }^{12}$ In general, judges are more independent, the less the government is involved in their appointment, (if relevant) the larger the legislative majorities needed for their confirmation, the longer their term of service, the smaller the risk of having their budgets reduced, the more difficult it is for the government to reverse unfavourable rulings, either by fresh legislation or by changing the charter or the composition of the judiciary (see Tridimas 2014 and the references therein).

\footnotetext{
11 An additional reason for endowing the judiciary with review powers is that it opens the opportunity for politicians to shift the blame for unpopular decisions to the independent national or international courts and avoid electoral defeat (Fiorina 1986). However, successful shift of responsibility for adverse policy impact requires that voters fail to see through underlying causes behind unpopular measures and remain irrational in the long-run.

12 Considering judicial independence as an explanatory variable, empirical research has shown that countries with higher degrees of judicial independence enjoy higher economic performance (Henisz 2000), greater economic and political freedom (La Porta et al. 2004), and a lower share of taxes (Tridimas 2005). Most interestingly, Feld and Voigt (2003) distinguish between de jure independence, as described in legal texts setting up the supreme court of a country, and de facto independence which is independence of the supreme court of a country as it is actually implemented in practice. They find that only de facto judicial independence is conducive to growth; a similar result is reported by Voigt et al. (2015).
} 
In the UK, the Act of Settlement 1701 confirmed the independence of the judiciary and the Constitutional Reform Act 2005 imposed a duty on executive officials to respect judicial independence. Parliament has put the security of tenure and salaries of senior judges beyond its own review. The UK Supreme Court was established by the Constitutional Reform Act of 2005. It took up the responsibilities of the Appellate Committee of the House of Lords, and of the Judicial Committee of the Privy Council for the devolved areas of Wales, Scotland and Northern Ireland. In a broad brush, the process for appointing Justices to the UK Supreme Court is as follows (see https://www.supremecourt.uk/docs/appointments-of-justices): The Lord Chancellor-Secretary of State for Justice convenes a selection commission chaired by the President of the Court, comprising a senior judge (but that judge cannot be a Justice of the Supreme Court). In addition, there is a member of each of the Judicial Appointments Commission for England and Wales, the Judicial Appointments Board in Scotland, and the Judicial Appointments Commission in Northern Ireland. These appointment commissions are independent bodies that select candidates for judicial office in courts and tribunals who select candidates on merit, through fair and open competition (https://www.judicialappointments.gov.uk). The commission must submit a report to the Lord Chancellor which must state who has been selected; who was consulted; and contains any other information required by the Lord Chancellor. Consultations then follow between the Lord Chancellor, senior judges, any other judge who has been consulted, the First Minister in Scotland, the First Minister in Wales and the Secretary of State for Northern Ireland. If, following these consultations, the Lord Chancellor is content with the recommendation made by the selection commission he forwards the person's name to the Prime Minister who, in turn, sends the recommendation to the Queen who makes the formal appointment.

\subsection{A rogue agent?}

Dispute resolution by the judiciary creates a new conflict. By finding in favour of one litigant and against another, the legitimacy of the court may come under attack by the loser. In order to overcome such problems courts base their rulings on generally accepted principles of justice, as expressed in formal laws and informal norms, and proclaim a normative justification for their decisions. More generally, and as highlighted by the principal-agent literature, the judiciary, as an agent with discretionary power this time, may pronounce rulings which serve its own interests instead of those of citizens and legislators (the principals). Indeed this is the usual criticism against decision making by unelected and unrepresentative judges, who often come from an elite social background. This implies the risk that independent courts may turn "rogue" and pursue deceitfully the personal and ideological interests of the judges. To safeguard against this risk a number of mechanisms have been established to secure judicial accountability, whereby accountability of an actor means that the actor is obliged to explain and justify its conduct and may be rewarded or sanctioned. Thence, the obligation of courts to publish and explain the reasons behind their decisions not only increases the information set available to all actors but also satisfies the requirement for accountability. A further constraint on the preferences 
of judges in judicial making is the norm of following court precedent or stare decisis (Knight and Epstein 1996).

However, a delicate balance must be struck here. If courts are held responsible for their decisions and forced to bear their costs, accountability may infringe their independence. Measures which aim to promote accountability may be abused and weaken judicial independence. ${ }^{13}$ Impeachment is probably the most potent measure for disciplining serving judges and removing them from office, but it can also be directed against judges with views different from those of the political rulers. As a result, it is a "cumbersome, costly and visible process that exposes [legislators] to electoral danger" (Ferejohn 1999, p. 358) and is only rarely used. Less drastically, an important restriction on judicial review is the binary nature of the rulings, that is, either to enforce a policy measure introduced by the government or annul it (Tridimas 2010).

The risk of courts going rogue is mitigated when one takes into account that courts as rational actors are interested in having their rulings obeyed and accepted, and rely on the cooperation of the other two arms of the state to implement their rulings (new legislation in accordance with the court ruling must be passed, or new administrative acts must be enacted). As a result, courts have an incentive to apply a form of "autolimitation" or self-restraint. ${ }^{14}$ Hence, their pronouncements will tend to be inside the "core" of the preferences of the parliament and the executive, that is, the set of policy points that cannot be defeated by any other proposal. Neither the legislature nor the executive will then have an incentive to pass new legislation to overturn the decision of the court or even change the charter of the court, weakening its power.

\section{Spatial decision equilibrium and the Supreme Court ruling}

This section uses the spatial model of public choice theory to illustrate the involvement of the Supreme Court in decision making. ${ }^{15}$ We assume a two-dimension choice space as shown in Fig. 1. On the horizontal axis we measure the degree of UK participation

\footnotetext{
13 This is the question of "quis custodiet ipsos custodes?" epitomised by the Roman poet Juvenal and traced to Plato. It is translated as "who will guard the guards?", or "who watches the watchmen?" See Cappelletti (1983) and Tiede (2006).

14 Shapiro (2002) argues that three factors contribute to successful implementation of judicial rulings: neutrality and independence of the court from the conflicting parties; an incremental, case-by-case, mode of judicial decision making; and the technical nature of its rulings. Neutrality means that litigants recognize that the judicial decision of who wins and who loses is determined by the law rather than the judges. Incremental ruling, that is, resolution of disputes case-by-case, has two advantages. First, it facilitates decision making in an uncertain and complex environment. Second, and perhaps more importantly, it allows resolution of disputes which involve "very small immediate stakes" but pronounce principles which form the precedence which will be observed in future dispute resolution of "grand issues of politics and policy". "Case-by-case judicial decision-making is, ..., a particularly good ground for easing into major policy change both by announcing big new law in small cases and by moving small doctrinal step by small doctrinal step into big changes" (p. 169). The technical nature of rulings removes party politics from the judicial decision, renders court rulings as well-informed responses in an uncertain environment, and presents judges as knowledgeable specialists whose pronouncements can be trusted.

15 See Ferejohn and Weingast (1992), Hanssen (2000), Vanberg (2001), Rogers (2001), Tsebelis (2002) and Stephenson (2004).
} 


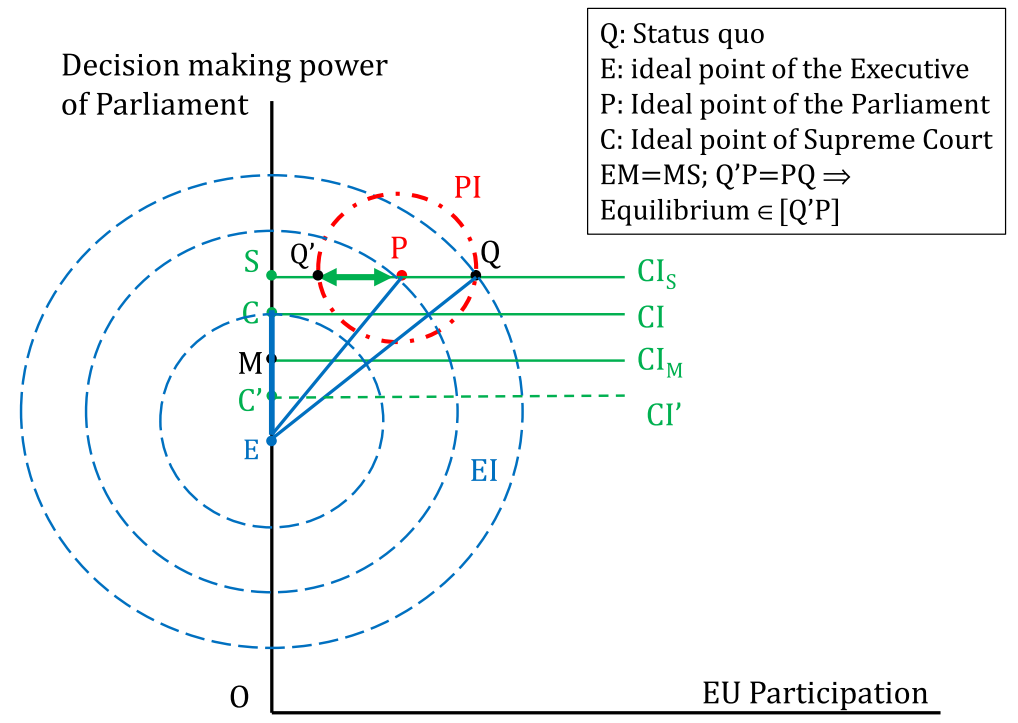

Fig. 1 Executive, Parliament and Supreme Court collective choice equilibrium in Parliament's power and EU Participation space

in the EU. The further away from the origin the more integrated the UK is with the EU. On the vertical axis we depict the decision making power of the Parliament vis-à-vis the Executive. The further away from the origin the more powerful the Parliament is. The status quo of full EU membership and decision making power of the Parliament is shown by point Q. The Parliament and the Executive, modelled as unitary actors, are assumed to have Euclidian preferences over the two dimensions so that the utility of each player increases the closer the power of the Parliament and terms of participation are to that player's ideal point. Points $\mathrm{P}$ and $\mathrm{E}$ show respectively the ideal points of the Parliament and the Executive, and the circles centred on P and E, PI and EI, show their indifference curves maps. With the Executive stylistically favouring Brexit without a deal (as the Johnson cabinet argued) and a minimal modicum of power for the Parliament, its ideal point $\mathrm{E}$ is on the vertical axis and close to the origin. On the other hand, the Parliament which wishes to preserve its power and retain closer ties to the EU (but not necessarily full participation), has an ideal point represented by $\mathrm{P}$ above and to the right of E. ${ }^{16}$ If the prorogation holds, the preferences of the Parliament are irrelevant to determining the collective choice equilibrium; the Executive takes the UK out of the $\mathrm{EU}$ without a deal, and point $\mathrm{E}$ is the new collective choice equilibrium.

Before introducing the Supreme Court as an additional player in the game of collective choice, we bring attention to two other important reference points. Point $S$ is the projection of $\mathrm{P}$ on the vertical axis and denotes the power of the Parliament vis-à-vis

\footnotetext{
${ }^{16}$ For concreteness, but without loss of generality, $\mathrm{P}$ is on the horizontal line from $\mathrm{Q}$ to the vertical axis, meaning that the ideal size of power of the Parliament vis-à-vis the Executive equals its actual power under the status quo.
} 
the Executive at the status quo. The segment SE, the distance between the ideal point of the Executive and the Parliament on the power of Parliament axis, shows the difference in the preferences of the Parliament and the Executive regarding the power of Parliament. Point $\mathrm{Q}^{\prime}$ is the point on the circle with radius PQ to the left of $\mathrm{P}$ on the SPQ line. With $\mathrm{Q}^{\prime} \mathrm{P}=\mathrm{PQ}$, the Parliament is indifferent between the status quo $\mathrm{Q}$ and its mirror $\mathrm{Q}^{\prime}$.

The dispute about the policy competencies of the Executive and the Parliament is resolved by the Supreme Court which clarifies the institutional setting and the legality of the actions of the other players. Specifically, the role of the Supreme Court is to interpret the constitution regarding the limits of parliamentary and executive power, but not to express preferences regarding the political issue of Brexit. The reason is that in accordance with rational choice theory, and in analogy to the other two players, the Supreme Court also has preferences about outcomes, but such preferences reflect the "deeply internalised" notions of justice held by judges, rather than political objectives. This means that, contrary to the Executive and the Parliament, the indifference curves of the Supreme Court reduce to horizontal lines. Suppose that the Court interprets the Constitution as granting power to the Parliament relative to the Executive represented by point $\mathrm{C}$ on the vertical axis. The Court's highest utility regarding the power of the Parliament is then represented by the indifference curve CI passing through point $\mathrm{C}$. Indifference curves above and below CI indicate lower levels of utility. The Court, however, does not have agenda setting power; it only has binary choice. That is, it either enforces the position proposed by the Executive or it annuls it by confirming the status quo; it cannot impose the outcome corresponding to its highest utility. It will nevertheless pronounce in favour of the position which is closer to its highest utility point. When, as in the Figure, $\mathrm{C}$ lies above the midpoint $\mathrm{M}$ of the segment $\mathrm{SE}(\mathrm{EM}=\mathrm{MS})$, the utility the Court derives from confirming the status quo is higher than the utility obtained from enforcing the ideal point of the Executive. Henceforth, if $\mathrm{C}$ lies above $\mathrm{M}$, the Court annuls the prorogation. This is exactly what the UK Supreme Court ruling ordered.

With the prorogation annulled the Executive can no longer set E; equilibrium is determined by taking into account the preferences about EU participation of both the Executive and the Parliament subject to the condition that the power of the Parliament is at the level represented by the line SQ'PQ. Given its preferences regarding EU participation, the Parliament is better off on points along the segment $Q^{\prime} Q_{\text {. With }}$ the Executive unable to establish E, forced to accept a point along SP and preferring points to the left of the status quo $\mathrm{Q}$, the collective choice equilibrium will be on a point along the segment $\mathrm{Q}^{\prime} \mathrm{P}$.

It is important to emphasise that the Court itself set out the test for determining the limits of executive powers to prorogue. The constitutional principles at issue limit executive prerogative power. The standard set by the Court to judge the limit is whether there was reasonable justification for suspending the Parliament for an unusually prolonged period of time. The Court held that the Executive did not offer sufficient justification. Hence, the Court is modeled as having a bliss point at $\mathrm{C}$. Given that the Court established the above legal standard, the only way the Executive might have won the case was if the Court had found that the Executive had offered a reasonable justification. Had it done so, the bliss point of the Court would 
have been represented by a point like $\mathrm{C}^{\prime}$ below $\mathrm{M}$. So the Court would have found for the Executive and validated the prorogation of Parliament.

It follows that the engagement of the Supreme Court in the UK collective choice game led to more UK participation than the Executive seemed to wish, thereby increasing the stability of the status quo. Very soon after the announcement of the Court ruling protestations against unelected and meddlesome judges subsided and related objections disappeared from headline news. The decision of the Supreme Court was accepted as final and the issue was closed. ${ }^{17}$ Executive officials comply with Court rulings proclaiming their ideology for the rule of law. Nevertheless, according to the rational choice model there are additional, and arguably, stronger motives for their self-restraint. Officials who defy the Court risk the disapproval of voters, other officials and of legal professionals. They may not be able to defend their actions and careers against such a public outcry. Moreover, following the insights of principal-agent theory, both the Executive and the Parliament are the principals who voluntarily delegate to the Court resolution of constitutional disputes generating a self-enforcing equilibrium; as a result they are bound to follow its rulings.

\section{Conclusions}

The previous analysis answers the question of whether the Supreme Court was rogue with a resounding no. In sum, the Court ruled that (1) the advice given by the Prime Minister to the Queen regarding the prorogation of Parliament is a matter subject to review by the UK courts. (2) The standards used to judge the lawfulness of the advice are the fundamental constitutional principles of parliamentary sovereignty to legislate and accountability of the executive to the parliament. (3) The act of proroguing failed the two standards. (4) As a result of the failure, the relevant remedy is to 'un-prorogue'.

Fully consistent with the delicate trade-off between judicial independence and judicial accountability, the Court treaded carefully by not expressing an opinion about the advantages and disadvantages of the political issue of Brexit, and delivered a verdict on the limits of executive discretion and the scope of parliamentary power in the UK as it has been established by statute, practice and convention. The reason for cancelling the prorogation of the Parliament was that in the UK the Parliament is sovereign and any measure which risks this foundational element of the Constitution is null and void. A strict interpretation of the ruling is that, contrary to judicial activism, the Supreme Court has been conservative and has reaffirmed the supremacy of Parliament. It has continued a tradition of deferring to the Parliament in major policy issues.

Acknowledgements We wish to thank an anonymous Referee for useful comments and suggestions and Alain Marciano and Giovanni Ramello for their guidance and encouragement in the pursuit of our research. We remain responsible for any errors and omissions.

\footnotetext{
17 The Parliament which resulted from the December 2019 election favoured exit from the EU; its ideal point on EU participation was also on the vertical axis and close enough to $\mathrm{E}$.
} 
Open Access This article is licensed under a Creative Commons Attribution 4.0 International License, which permits use, sharing, adaptation, distribution and reproduction in any medium or format, as long as you give appropriate credit to the original author(s) and the source, provide a link to the Creative Commons licence, and indicate if changes were made. The images or other third party material in this article are included in the article's Creative Commons licence, unless indicated otherwise in a credit line to the material. If material is not included in the article's Creative Commons licence and your intended use is not permitted by statutory regulation or exceeds the permitted use, you will need to obtain permission directly from the copyright holder. To view a copy of this licence, visit http://creativecommons.org/licen ses/by/4.0/.

\section{Appendix}

Timeline of referendum, elections, legislation and court rulings. Source: Compiled by the authors

Date Event

\section{6}

23 June

24 June

13 July

02 October

3 November

2017

24 January

16 March

29 March

08 June
EU Referendum; 51.9-48.1\% victory for the 'Out'

David Cameron resigns as Leader of the Conservatives and Prime Minister

Theresa May becomes Prime Minister

Theresa May announces intention to give notice under article 50 for the UK to exit the EU before the end of March 2017

Gina Miller and others challenged her power to do so without the authority of an Act of Parliament

In response to a challenge by Gina Miller, the High Court rules that Parliament had to legislate before the Government could invoke Article 50

On appeal by the Government against the High Court ruling, the Supreme Court rules that the Prime Minister had no power to take the country out of the EU without the vote of Parliament

The Parliament passes the European Union (Notification of Withdrawal) Act 2017 authorising the Prime Minister to give the notification for withdrawal

Theresa May gives notification of withdrawal; 29 March 2019 set as exit date

Parliamentary election resulted in hung parliament:

$\begin{array}{lll}\text { Party } & \text { Vote share (\%) } & \text { Number of seats } \\ \text { Conservative } & 42.2 & 317 \\ \text { Labour } & 40.0 & 262 \\ \text { Scottish National } & 3.0 & 35 \\ \text { Liberal Democrats } & 7.4 & 12 \\ \text { Democratic Unionist } & 0.9 & 10 \\ \text { Sinn Fein } & 0.7 & 7 \\ \text { Plaid Cymru } & 0.5 & 4 \\ \text { Other } & 5.3 & 3 \\ \text { Democratic Unionist Party: Northern Ireland Unionists } & \\ \text { Sinn Fein: Northern Ireland Nationalists who do not take their Westminster seats } \\ \text { Plaid Cymru: Welsh Nationalist } \\ \text { The European Union (Withdrawal) Act 2018 comes into force }\end{array}$




Date Event

\section{8}

25 November Negotiations with the EU over withdrawal agreement concluded 2019

15 January

Parliament rejects the withdrawal agreement by 432-202 votes

12 March

29 March

08 April

10 April

07 June

24 July

30 July

27-28 August

3 September

04 September

04 September

09 September

11 September

13 September

24 September

24 September

28 October

29 October

12 December

Parliament rejects the withdrawal agreement by 391-242 votes

Parliament rejects the withdrawal agreement by 344-286 votes an extension for leaving the EU

Extension granted by the EU until 31st October 2019 tember-10 October

\section{Parliament returns from summer recess} withdrawal agreement or approved leaving without one

Parliament is prorogued the Parliament

Parliament resumes its business

Extension granted by the EU until 31st January 2020

Commons pass legislation for an early election

Parliamentary election
Parliament passes the European Union (Withdrawal) Act 2019 requiring the PM to seek

Theresa May resigns as Leader of the Conservatives and Prime Minister

Boris Johnson becomes Prime Minister after the resignation Theresa May

A cross-party group of MPs petitions the Outer House of the Scottish Court of Session that a prorogation of Parliament would be unlawful and seeks interdict to prevent it

The Prime Minister advises the Queen to prorogue Parliament for the period 09 Sep-

Gina Miller launches proceedings in the High Court in England and Wales, seeking a declaration that the Prime Minister's advice to the Queen was unlawful

Court of Session refuses petition on the basis that the issue was not justiciable

Parliament seizes order of the day from Government and legislates that the Prime Minister seeks three-month extension unless Parliament has by then either approved a

The High Court dismisses the claim that the advice of the PM to the Queen was unlawful as not justiciable. Gina Miller appeals; the case moves to the UK Supreme Court The Inner House of the Court of Session allows appeal against the Outer House ruling. The Advocate General appeals; the case moves to the UK Supreme Court

The Supreme Court finds unanimously that the question of the power to prorogue is justiciable and that the Government had not provided any good reason for proroguing

Party

Conservative

Vote Share (\%)

Number of Seats

Labour

Scottish National

32.2

203

Liberal Democrats

3.9

48

Democratic Unionist

11.5

11

Sinn Fein

0.8

8

Plaid Cymru

0.6

7

Other

0.5

4

6.9

31 January The UK leaves the European Union 


\section{References}

Bogdanor, V. (2009). The British constitution. Portland, OR: Hart Publishing.

Bradley, A. W., Ewing, K. D., \& Knight, C. J. S. (2018). Constitutional and administrative law. Harlow: Person.

Cappelletti, M. (1983). Who watches the watchmen? A comparative study on judicial responsibility. The American Journal of Comparative Law, 31, 1-62.

Congleton, R. D. (2011). Perfecting parliament: Constitutional reform and the origins of western democracy. New York: Cambridge University Press.

Feld, P. L., \& Voigt, S. (2003). Economic growth and judicial independence: Cross country evidence using a new set of indicators. European Journal of Political Economy, 19, 497-527.

Ferejohn, J. A. (1999). Independent judges, dependent judiciary: Explaining judicial independence. Southern California Law Review, 72, 353-384.

Ferejohn, J. A. (2002). Judicializing politics, politicizing law. Law and Contemporary Problems, 65, 41-68.

Ferejohn, J. A., \& Weingast, B. R. (1992). A positive theory of statutory interpretation. International Review of Law and Economics, 12, 263-279.

Fiorina, M. (1986). Legislator uncertainty, legislative control and the delegation of legislative power. Journal of Law and Economics, 2, 33-51.

Ginsburg, T. (2002). Economic analysis and the design of constitutional courts. Theoretical Inquiries in Law, $3,49-85$.

Hanssen, F. A. (2000). Independent courts and administrative agencies: An empirical analysis of the states. Journal of Law Economics and Organization, 16, 534-571.

Hanssen, F. A. (2004). Is there a politically optimal level of judicial independence? American Economic Review, 94, 712-799.

Harnay, S. (2005). Judicial independence. In J. Backhaus (Ed.), The Elgar companion to law and economics (pp. 407-423). Cheltenham: Edward Elgar.

Hayo, B., \& Voigt, S. (2007). Explaining de facto judicial independence. International Review of Law and Economics, 27, 269-290.

Henisz, W. J. (2000). The institutional environment for economic growth. Economics and Politics, 12, $1-31$.

Ip, E. C. (2014). The judicial review of legislation in the United Kingdom: A public choice analysis. European Journal of Law and Economics, 37, 221-247.

Kavanagh, A. (2009). Constitutional review under the Human Rights Act. Cambridge: Cambridge University Press.

Knight, J., \& Epstein, L. (1996). Stare decisis. American Journal of Political Science, 40, 1018-1035.

La Porta, R., Lopez-de-Silanes, F., Pop-Eleches, C., \& Shleifer, A. (2004). Judicial checks and balances. Journal of Political Economy, 112, 445-470.

Landes, W., \& Posner, R. (1975). The independent judiciary in an interest-group perspective. Journal of Law and Economics, 18, 875-911.

Law, D. S. (2009). A theory of judicial power and judicial review. Georgetown Law Journal, 97, 723-801.

Majone, G. (2001). Two logics of delegation: Agency and fiduciary relations in EU governance. European Union Politics, 2, 103-122.

Maskin, E., \& Tirole, J. (2004). The politician and the judge: Accountability in government. American Economic Review, 94, 1034-1054.

Mueller, D. C. (1996). Constitutional democracy. Oxford: Oxford University Press.

Ramseyer, M. J. (1994). The puzzling (in)dependence of courts: A comparative approach. Journal of Legal Studies, 33, 721-747.

Rogers, J. R. (2001). Information and judicial review: A signalling game of the legislative-judicial interaction. American Journal of Political Science, 45, 84-99.

Shapiro, M. (2002). The success of judicial review and democracy. In M. Shapiro \& A. Stone Sweet (Eds.), On law, politics and judicialization (pp. 149-183). Oxford: Oxford University Press.

Shapiro, M., \& Stone Sweet, A. (2002). Constitutional judicial review. In M. Shapiro \& A. Stone Sweet (Eds.), On law, politics, and judicialization (pp. 138-148). Oxford: Oxford University Press.

Stephenson, M. C. (2004). Court of public opinion: Government accountability and judicial independence. Journal of Law Economics and Organization, 20, 379-399.

Stone Sweet, A. (2002). Constitutional courts and parliamentary democracy. West European Politics, 25, 77-100. 
Tiede, L. B. (2006). Judicial independence: Often cited, rarely understood. Journal of Contemporary Legal Issues, 15, 129-261.

Tridimas, G. (2005). Judges and taxes: Judicial review, judicial independence and the size of government. Constitutional Political Economy, 16, 5-30.

Tridimas, G. (2010). Constitutional judicial review and political insurance. European Journal of Law and Economics, 29, 81-101.

Tridimas, G. (2014). Independent judiciary. In A. Marciano \& G. Ramello (Eds.), Encyclopedia of law and economics. New York NY: Springer.

Tsebelis, G. (2002). Veto players: How political institutions work. Princeton, NJ: Princeton University Press.

Vanberg, G. (2001). Legislative-judicial relations: A game theoretic approach to constitutional review. American Journal of Political Science, 48, 346-361.

Voigt, S. (2020). Constitutional political economy. A primer. Cambridge: Cambridge University Press. (in press).

Voigt, S., Gutmann, J., \& Feld, L. P. (2015). Economic growth and judicial independence, a dozen years on: Cross-country evidence using an updated set of indicators. European Journal of Political Economy, 38, 197-211.

Weingast, B. (1993). Constitutions as governance structures: The political foundations of secure markets. Journal of Institutional and Theoretical Economics, 149, 286-311.

Publisher's Note Springer Nature remains neutral with regard to jurisdictional claims in published maps and institutional affiliations. 